\title{
The effect of ambient temperature on the thiamin requirement of growing-finishing pigs
}

\author{
By C.-L. PENG* and H. HEITMAN JR \\ Department of Animal Science, University of California, Davis 95616, USA
}

(Received 4 January 1972-Accepted 4 February 1974)

\begin{abstract}
1. Three experiments involving sixty-two growing-finishing pigs from 28 to $90 \mathrm{~kg}$ bodyweight were conducted to investigate the effect of environmental temperature on the thiamin requirement of growing-finishing pigs. Three temperatures $\left(20^{\circ}, 30^{\circ}\right.$ and $\left.35^{\prime \prime}\right)$ were used.

2. Under these experimental conditions, average daily weight gain indicated no effect of environmental temperature on thiamin requirement. By using erythrocyte transketolase (EC 2.2.I.I) activity and its percentage stimulation by thiamin pyrophosphate (TPP stimulation per cent) as criteria, there was a significant effect of environmental temperature on the thiamin requirement of growing-finishing pigs. At $20^{\circ}$, the thiamin requirement for maintaining maximum transketolase activity or minimum TPP stimulation per cent was found to be approximately $3.3 \mathrm{mg} / \mathrm{kg}$ diet; at $30^{\circ}$, the requirement was between 3.7 and $4.0 \mathrm{mg} / \mathrm{kg}$ diet. As estimated from erythrocyte transketolase activity, and the rate of 'TPP stimulation per cent increase, the thiamin requirement might be higher than $4.0 \mathrm{mg} / \mathrm{kg}$ diet at $35^{\circ}$.

3. There was a significant effect of environmental temperature on daily weight gain and food intake. The rate of weight gain and food intake decreased with increasing temperature. The efficiency of food utilization generally showed no significant differences among temperatures.
\end{abstract}

Many nutrient recommendations are made in terms of daily requirements, disregarding the absolute food intake of the animal. At high environmental temperatures daily food intake is reduced (Heitman \& Hughes, 1949) and little is known about whether recommendations for specific nutrients, such as the vitamins for example, should be increased under these circumstances. In addition, environmental temperature modifies the metabolism of carbohydrate and protein (Hart, 1958), and, since thiamin has been shown to be of significance in the metabolism of both these nutrients, the thiamin requirement may vary with temperature. Mitchell (1964) discussed his unpublished findings which indicated that a low environmental temperature decreased the pig's thiamin requirement. Also, Mills (I94I) reported that the thiamin need per unit of diet is increased at high temperature in the rat. In contrast to these results, Grab \& Lancy (1944), Ershoff (1950), and Hegsted \& McPhee (1950) reported that rats required more thiamin per unit of diet at a lower than at a higher temperature. However, Vaughan \& Vaughan (1957) reported that, for weight response, the thiamin requirement of adult rats was similar at $5^{\circ}$ and $25^{\circ}$.

The use of erythrocyte transketolase ( $E C$ 2.2.1. I) activity and thiamin pyrophosphate (TPP) stimulation per cent (i.e. the increase in transketolase activity in a deficient haemolysate due to the addition of TPP before incubation expressed as a percentage of that in the deficient haemolysate incubated without the addition of TPP) as criteria for evaluating the thiamin status of growing-finishing pigs has been reported by Peng \& Heitman (1973).

- Present address: Betagro Co. Ltd, 40 Yukhon I Rd (Suan Mali), Bangkok I, Thailand. 
The experiments reported herein were conducted to further investigate the effect of ambient temperature on the thiamin requirement of growing-finishing pigs using erythrocyte transketolase activity and TPP stimulation per cent as criteria.

\section{EX P ERIM EN TAL}

\section{Buildings and equipment}

The basic buildings used were insulated trailers which were adapted for environmental studies by Givens, Morrison, Bond \& Miller (197I) and the psychrometric chamber which has been remodelled since first described by Heitman, Kelly \& Hughes (1949). The two trailers contained eight crates $(1.52 \mathrm{~m}$ long $\times 0.58 \mathrm{~m}$ wide $\times 1.07 \mathrm{~m}$ high) each, and the chamber contained two houses $(2.74 \mathrm{~m}$ long $\times 1 \cdot 22 \mathrm{~m}$ wide $\times$ I.09 $\mathrm{m}$ high).

\section{Experimental diet}

The composition of a sucrose diet was as given by Peng \& Heitman (I973) except that the vitamin premix was changed in the diet as follows: $95^{\circ} \mathrm{kg}$ sucrose was mixed with $67 \mathrm{mg}$ retinol equivalent as retinyl palmitate, $500 \mu \mathrm{g}$ ergocalciferol, I $\mathrm{g} \mathrm{DL}-\alpha$ tocopheryl acetate, $330 \mathrm{mg}$ riboflavin, $\mathrm{I} \cdot 65 \mathrm{~g}$ nicotinic acid, $\mathrm{I} \cdot 65 \mathrm{~g}$ calcium pantothenate, $230 \mathrm{mg}$ pyridoxine hydrochloride, $1 \cdot 3 \mathrm{mg}$ cyanocobalamin, $20 \mathrm{mg}$ biotin, $100 \mathrm{mg}$ pteroylmonoglutamic acid and $50 \mathrm{~g}$ choline chloride. Ration $\mathrm{I}$, which contained an estimated $\mathrm{r} 60 \mathrm{~g}$ crude protein $(\mathrm{N} \times 6.25) / \mathrm{kg}$, was for $25-45.5 \mathrm{~kg}$ pigs; ration 2, which contained an estimated $140 \mathrm{~g}$ crude protein $/ \mathrm{kg}$ (substituting $20 \mathrm{~g}$ sugar for $20 \mathrm{~g}$ casein, in ration I), was for $45 \cdot 5-90 \mathrm{~kg}$ pigs. The diet variable, thiamin level, was applied to the eight crates and two chamber houses within temperature treatment.

\section{Animals and their management}

Duroc barrows (male pigs castrated before the development of secondary sexual characteristics, in this instance at about 7 weeks of age) were obtained from the University farm. The pigs were given the regular pig ration (by analysis, $4.44 \mathrm{mg}$ thiamin $/ \mathrm{kg}$ ) before being assigned to treatments. The initial body-weight of the pigs averaged $42 \cdot 2,33 \cdot 4$ and $32 \cdot \mathrm{I} \mathrm{kg}$ for Expts $\mathrm{I}, 2$ and 3 , respectively. The pigs from six litters were randomly allocated to the experimental treatments in a factorial design (temperature $x$ dietary thiamin level). The numbers of pigs per treatment are shown in the tables. Pigs were housed in individual crates in the trailers or in a group in the chamber houses. The pigs remained in the experiment for ro weeks. The dictary levels of thiamin and environmental temperature used in each experiment are shown in the tables and figures. The results were analysed statistically using analysis of variance. Tests for significance of differences were made by Duncan's (I955) multiple-range test.

\section{Blood sampling and analytical methods}

Collection of blood samples and methods of analysis were those described by Peng \& Heitman (1973). 
Table I. Summated means of the effect of dietary thiamin level on weight gain, food intake, intake:wt gain ratio, thiamin pyrophosphate (TPP) stimulation per cent (see p. I) and transketolase activity of pigs*

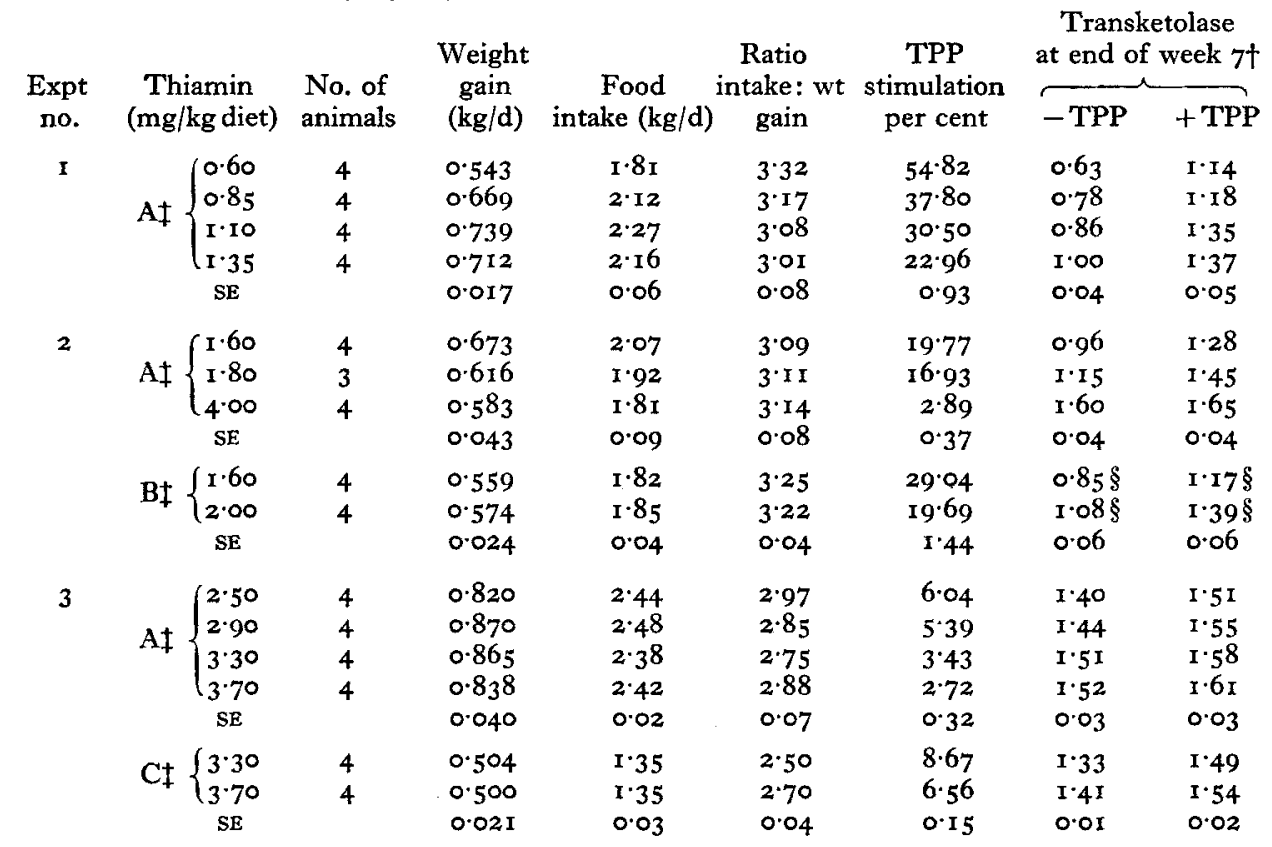

* TPP stimulation per cent is the mean for 8 weeks. Weight gain and food intake were measured over a ro-week period.

$\dagger$ Values expressed as $\mathrm{mg}$ hexose formation $/ \mathrm{ml}$ haemolysate per $\mathrm{h}:(-)$ denotes no addition; $(+)$ denotes the addition of TPP to each haemolysate.

$\ddagger \mathbf{A}$, mean values for two temperatures $\left(20^{\circ}\right.$ and $\left.30^{\circ}\right) ; \mathrm{B}$, mean values for two temperatures $\left(20^{\circ}\right.$ and $\left.35^{\circ}\right)$; $\mathrm{C}$, mean values for one temperature $\left(35^{\circ}\right)$.

$\$$ Mean values for five animals.

\section{RESULTS AND DISCUSSION}

Weight gain, food intake and food utilization. The main effects of thiamin and of temperature are presented in Tables $I$ and 2. Interaction was tested and lacked statistical significance. Dietary thiamin level had a significant effect on daily weight gain and food intake. The results show that the greatest response resulted from the first increment of from 0.60 to $0.85 \mathrm{mg}$ thiamin/kg diet in Expt I. In Expt I, a further increase in thiamin level to $\mathrm{I} \cdot \mathrm{I} O \mathrm{mg} / \mathrm{kg}$ caused a small but significant increase in weight gain. Higher thiamin levels were tested in the other experiments. Maximum weight gains were obtained in Expt 3, but low weight gains were obtained in Expt 2. Increments in thiamin level above $1.10 \mathrm{mg} / \mathrm{kg}$ had no significant effect on daily weight gain, and increments above $0.85 \mathrm{mg} / \mathrm{kg}$ had no significant effect on food intake.

Environmental temperature had a significant effect $(P<0.01)$ on daily weight gain and daily food intake, except between $20^{\circ}$ and $30^{\circ}$ in Expt 2. The pigs housed at $20^{\circ}$ gained weight faster and also ate more food than those at $30^{\circ}$. As the air temperature increased further to $35^{\circ}$, the daily food intake decreased more markedly, and this 
Table 2. Summated means of the effect of temperature on weight gain, food intake, intake:wt gain ratio, thiamin pyrophosphate (TPP) stimulation per cent (see p. 1) and transketolase activity of pigs*

\begin{tabular}{|c|c|c|c|c|c|c|c|c|}
\hline \multirow{2}{*}{$\begin{array}{c}\text { Expt } \\
\text { no. }\end{array}$} & \multirow{2}{*}{$\begin{array}{c}\text { Tem- } \\
\text { perature }\end{array}$} & \multirow{2}{*}{$\begin{array}{l}\text { No. of } \\
\text { animals }\end{array}$} & \multirow{2}{*}{$\begin{array}{c}\text { Weight } \\
\text { gain } \\
(\mathrm{kg} / \mathrm{d})\end{array}$} & \multirow{2}{*}{$\begin{array}{c}\text { Food } \\
\text { intake }(\mathrm{kg} / \mathrm{d})\end{array}$} & \multirow{2}{*}{$\begin{array}{c}\text { Ratio } \\
\text { intake: wt } \\
\text { gain }\end{array}$} & \multirow{2}{*}{$\begin{array}{c}\text { TPP } \\
\text { stimulation } \\
\text { per cent }\end{array}$} & \multicolumn{2}{|c|}{$\begin{array}{c}\text { Transketolase } \\
\text { at end of week 7† }\end{array}$} \\
\hline & & & & & & & - TPP & $+{ }^{\prime T} \mathrm{TPP}$ \\
\hline I & $\begin{aligned} A \pm\left\{\begin{array}{l}20^{\circ} \\
30^{\circ}\end{array}\right. & S \mathrm{SE}\end{aligned}$ & $\begin{array}{l}8 \\
8\end{array}$ & $\begin{array}{l}0.821 \\
0.510 \\
0.012\end{array}$ & $\begin{array}{l}2 \cdot 55 \\
1 \cdot 62 \\
0.05\end{array}$ & $\begin{array}{l}3 \cdot 11 \\
3 \cdot 17 \\
0.06\end{array}$ & $\begin{array}{r}40.39 \\
32.64 \\
0.66\end{array}$ & $\begin{array}{l}0.81 \\
0.82 \\
0.03\end{array}$ & $\begin{array}{l}1 \cdot 34 \\
1 \cdot 18 \\
0 \cdot 04\end{array}$ \\
\hline & $\begin{aligned} & \mathrm{B} \pm\left\{\begin{array}{l}20^{\circ} \\
30^{\circ}\end{array}\right. \\
& \mathrm{SE}\end{aligned}$ & $\begin{array}{l}6 \\
5\end{array}$ & $\begin{array}{l}0.632 \\
0.645 \\
0.035\end{array}$ & $\begin{array}{l}2 \cdot 09 \\
1 \cdot 83 \\
0.08\end{array}$ & $\begin{array}{l}3.30 \\
2.85 \\
0.07\end{array}$ & $\begin{array}{r}13.37 \\
14.31 \\
0.30\end{array}$ & $\begin{array}{l}1 \cdot 20 \\
1 \cdot 25 \\
0 \cdot 03\end{array}$ & $\begin{array}{l}1.40 \\
1.48 \\
0.03\end{array}$ \\
\hline & $\mathrm{Ct}\left\{\begin{array}{l}20^{\circ} \\
35^{\circ}\end{array}\right.$ & $\begin{array}{l}4 \\
4\end{array}$ & $\begin{array}{l}0.646 \\
0.458 \\
0.025\end{array}$ & $\begin{array}{l}2 \cdot 12 \\
1 \cdot 41 \\
0.04\end{array}$ & $\begin{array}{l}3.28 \\
3.08 \\
0.04\end{array}$ & $\begin{array}{c}17 \cdot 16 \\
29 \cdot 90 \$ \\
1 \cdot 44\end{array}$ & $\begin{array}{l}1.03 \\
0.90 \$ \\
0.06\end{array}$ & $\begin{array}{l}1 \cdot 30 \\
1 \cdot 27 \$ \\
0.06\end{array}$ \\
\hline 3 & DIf $\left\{\begin{array}{l}20^{\circ} \\
30^{\circ}\end{array}\right.$ & $\begin{array}{l}8 \\
8\end{array}$ & $\begin{array}{l}1.016 \\
0.680 \\
0.029\end{array}$ & $\begin{array}{l}2 \cdot 85 \\
1 \cdot 99 \\
0.07\end{array}$ & $\begin{array}{l}2 \cdot 85 \\
2.93 \\
0.05\end{array}$ & $\begin{array}{l}3 \cdot 25 \\
5.54 \\
0.23\end{array}$ & $\begin{array}{l}I .54 \\
1.40 \\
0.02\end{array}$ & $\begin{array}{l}1 \cdot 60 \\
1.52 \\
0.02\end{array}$ \\
\hline & $\mathrm{C} \pm\left\{\begin{array}{c}20^{\circ} \\
30^{\circ} \\
35^{\circ} \\
\mathrm{SE}\end{array}\right.$ & $\begin{array}{l}4 \\
4 \\
8\end{array}$ & $\begin{array}{l}1.013 \\
0.690 \\
0.520 \\
0.015\end{array}$ & $\begin{array}{l}2 \cdot 80 \\
1 \cdot 96 \\
1 \cdot 35 \\
0.02\end{array}$ & $\begin{array}{l}2 \cdot 76 \\
2 \cdot 84 \\
2 \cdot 60 \\
0.03\end{array}$ & $\begin{array}{l}2.09 \\
4.05 \\
7.61 \\
0.23\end{array}$ & $\begin{array}{l}I \cdot 60 \\
I \cdot 44 \\
1 \cdot 39 \\
0.01\end{array}$ & $\begin{array}{l}1.63 \\
1.56 \\
1 \cdot 52 \\
0.01\end{array}$ \\
\hline
\end{tabular}

- TPP stimulation per cent is the mean for 8 weeks. Weight gain and food intake were measured over a ro-week period.

+ Values expressed as $\mathrm{mg}$ hexose formation/ml haemolysate per $\mathrm{h}:(-)$ denotes no addition; $(+)$ denotes the addition of TPP to each haemolysate.

$\ddagger A$, mean values for four thiamin levels $(0 \cdot 60,0.85,1 \cdot 10$ and $\mathrm{r} \cdot 35)$; B, mean values for three thiamin levels ( $1 \cdot 60,1 \cdot 80$ and $4 \cdot 00)$; C, mean values for two thiamin levels ( $1 \cdot 60,2 \cdot 00$ in Expt 2 and $3 \cdot 3 \circ, 3 \cdot 70$ in Expt 3); D, mean values for four thiamin levels $(2 \cdot 50,2 \cdot 90,3.30$ and 3.70$)$.

$\$$ Mean values for six animals.

\section{Table 3. Expt I. Effect of dietary thiamin level and ambient temperature on thiamin pyrophosphate (TPP) stimulation per cent (see p. $\mathrm{I}$ ) in pigs}

\begin{tabular}{|c|c|c|c|c|c|c|c|c|c|}
\hline \multirow{3}{*}{$\begin{array}{l}\text { Temperature } \\
\text { Thiamin } \\
\text { (mg/kg } \\
\text { diet) } \ldots\end{array}$} & \multicolumn{8}{|c|}{ (Mean values for two animals) } & \multirow{3}{*}{$\begin{array}{c}S E \text { of } \\
\text { the mean }\end{array}$} \\
\hline & \multirow{2}{*}{$\begin{array}{l}\cdots \\
0.60\end{array}$} & \multicolumn{2}{|c|}{$20^{\circ}$} & \multirow[b]{2}{*}{ I.35 } & \multicolumn{3}{|c|}{$30^{\circ}$} & \multirow[b]{2}{*}{$1 \cdot 35$} & \\
\hline & & 0.85 & $1 \cdot 10$ & & 0.60 & 0.85 & $I \cdot 10$ & & \\
\hline $\begin{array}{l}\text { Weeks } \\
\text { on diet }\end{array}$ & & & & & & & & & \\
\hline$\circ$ & $2 \cdot 44$ & $2 \cdot 80$ & $2 \cdot 83$ & 3.00 & $2 \cdot 95$ & $2 \cdot 43$ & $2 \cdot 57$ & $2 \cdot 26$ & 0.30 \\
\hline $\mathbf{x}$ & $15 \cdot 21$ & I I 35 & $12 \cdot 14$ & $7 \cdot 33$ & I 7.04 & $9 \cdot 02$ & II 42 & 10.20 & 0.89 \\
\hline 2 & $33 \cdot 30$ & $20 \cdot 90$ & $18 \cdot 58$ & $12 \cdot 50$ & $25 \cdot 35$ & 18.64 & $17 \cdot 47$ & 13.00 & $2 \cdot 10$ \\
\hline 3 & $38 \cdot 79$ & $31 \cdot 63$ & $22 \cdot 59$ & $18 \cdot 92$ & $32 \cdot 98$ & $26 \cdot 49$ & $19 \cdot 10$ & $15 \cdot 14$ & $2 \cdot 87$ \\
\hline 4 & $59 \cdot 43$ & $47 \cdot 6 \mathrm{I}$ & 25.52 & $19 \cdot 83$ & $42 \cdot 45$ & 26.94 & $26 \cdot 82$ & $2 \mathrm{I} \cdot 53$ & $2 \cdot 28$ \\
\hline 5 & 70.52 & $56 \cdot 66$ & $36 \cdot 73$ & $25 \cdot 13$ & 54.50 & $32 \cdot 28$ & 29.59 & 25.34 & 3.10 \\
\hline 6 & $72 \cdot 09$ & 59.09 & $3^{8 \cdot 57}$ & 28.00 & $6 \mathrm{I} \cdot 93$ & 32.44 & 30.44 & 26.82 & 1.09 \\
\hline $\begin{array}{l}7 \\
8\end{array}$ & $\begin{array}{r}95.43 \\
102.29\end{array}$ & $\begin{array}{l}65.71 \\
80.50\end{array}$ & $\begin{array}{l}46 \cdot 32 \\
58 \cdot 60\end{array}$ & $\begin{array}{l}38 \cdot 92 \\
49 \cdot 50\end{array}$ & $\begin{array}{l}75 \cdot 75 \\
80.92\end{array}$ & $\begin{array}{l}41 \cdot 50 \\
53.62\end{array}$ & $\begin{array}{l}32 \cdot 94 \\
42 \cdot 60\end{array}$ & $\begin{array}{l}30.01 \\
35.24\end{array}$ & $\begin{array}{l}5.33 \\
3 \cdot 92\end{array}$ \\
\hline Mean & 60.55 & $45 \cdot 64$ & $32 \cdot 22$ & $23 \cdot 19$ & $49 \cdot 10$ & 29.96 & $28 \cdot 78$ & $22 \cdot 74$ & 0.46 \\
\hline
\end{tabular}


Table 4. Expt 2. Effect of dietary thiamin level and ambient temperature on thiamin pyrophosphate (TPP) stimulation per cent (see p. 1 ) in pigs

(Mean value for two animals at $20^{\circ}$ and $30^{\circ}$ and for three animals at $35^{\circ}$, except where stated)

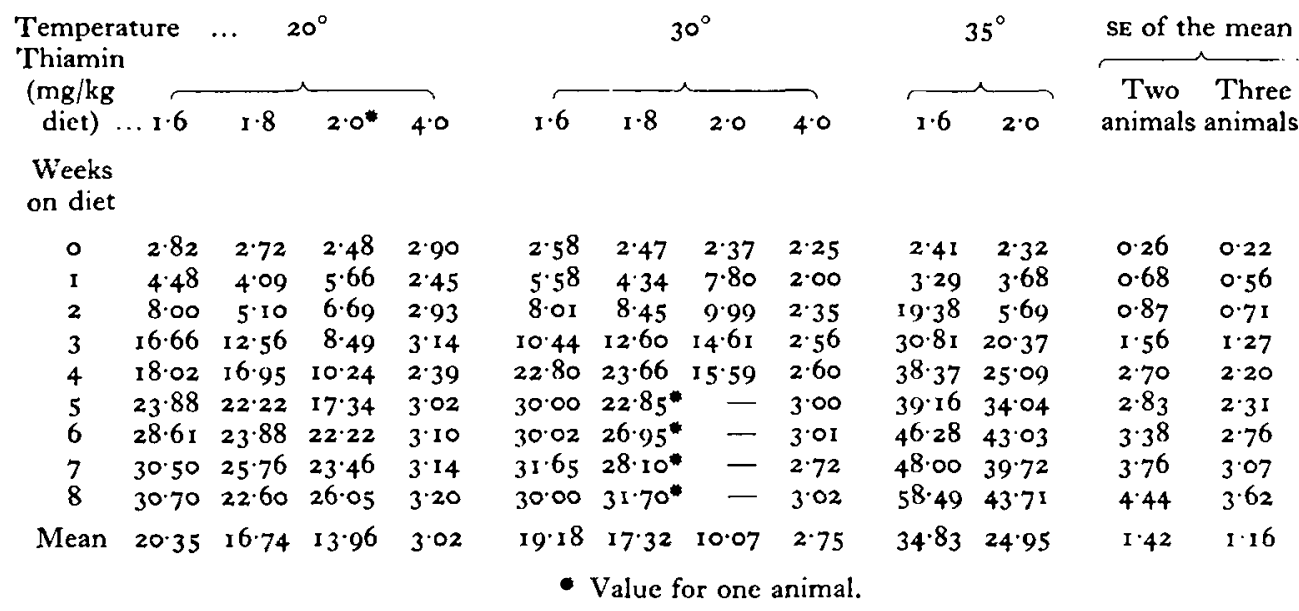

Table 5. Expt 3. Effect of dietary thiamin level and ambient temperature on thiamin pyrophosphate (TPP) stimulation per cent (see p. I) in pigs

(Mean value for two animals at $20^{\circ}$ and $30^{\circ}$ and for four animals at $35^{\circ}$ )

\begin{tabular}{|c|c|c|c|c|c|c|c|c|c|c|c|c|}
\hline \multirow{2}{*}{$\begin{array}{c}\text { Temperat } \\
\text { Thiamin } \\
\text { (mg/kg } \\
\text { diet) ... }\end{array}$} & \multicolumn{3}{|c|}{$\ldots \quad 20^{\circ}$} & & \multicolumn{4}{|c|}{$30^{\circ}$} & \multicolumn{2}{|c|}{$35^{\circ}$} & \multicolumn{2}{|c|}{$\mathrm{SE}$ of the mean } \\
\hline & & 2.9 & 3.3 & 37 & 2.5 & 2.9 & 3.3 & 3.7 & 3.3 & 3.7 & $\begin{array}{c}\text { Two } \\
\text { animals }\end{array}$ & $\begin{array}{l}\text { Four } \\
\text { animals }\end{array}$ \\
\hline \multicolumn{13}{|l|}{$\begin{array}{l}\text { Weeks } \\
\text { on diet }\end{array}$} \\
\hline 0 & 1.62 & $I \cdot 55$ & I' 54 & $2 \cdot 10$ & $1 \cdot 62$ & $1 \cdot 79$ & $\mathrm{I} \cdot 68$ & $I \cdot 56$ & $x \cdot 49$ & $1 \cdot 74$ & 0.21 & O.I 5 \\
\hline I & $2 \cdot 38$ & $\mathrm{I} \cdot 93$ & $2 \cdot 20$ & $2 \cdot 44$ & $2 \cdot 32$ & $2 \cdot 51$ & $2 \cdot 52$ & $2 \cdot 08$ & $2 \cdot 15$ & $2 \cdot 4^{8}$ & 0.28 & 0.20 \\
\hline 2 & 3.55 & $3 \cdot 33$ & $2 \cdot 55$ & $1 \cdot 54$ & 4.81 & $2 \cdot 64$ & $I \cdot 53$ & $I \cdot 5 I$ & 4.98 & $3 \cdot$ I I & 0.32 & 0.23 \\
\hline 3 & 4.10 & $4.3^{8}$ & $2 \cdot 19$ & 1.62 & 6.26 & $6 \cdot 28$ & 3.09 & $x \cdot 60$ & $7 \cdot 98$ & 4.54 & 0.34 & 0.24 \\
\hline 4 & 5.24 & 4.46 & $2 \cdot 39$ & $2 \cdot 12$ & 7.91 & $7 \cdot 61$ & 2.79 & $2 \cdot 51$ & 9.08 & 5.91 & 0.44 & $0.3 I$ \\
\hline 5 & 473 & 5.09 & $2 \cdot 17$ & 1.88 & 9.57 & 759 & 4.27 & $3 \cdot 17$ & 9.42 & $7 \cdot 52$ & 0.54 & $0.3^{8}$ \\
\hline 6 & 5.28 & 5.06 & 2.93 & $1 \cdot 82$ & 10.17 & $7 \cdot 88$ & 6.55 & 5.56 & I I 77 & $8 \cdot 74$ & 0.63 & 0.44 \\
\hline 7 & 6.98 & $5 \cdot 88$ & 2.52 & 1.83 & 10.42 & 10.03 & $8 \cdot 7$ I & 6.59 & $14.5 \mathrm{I}$ & I I 04 & 0.83 & 0.59 \\
\hline 8 & $7 \cdot 28$ & 6.53 & $2 \cdot 81$ & $1 \cdot 26$ & 14.99 & 12.53 & $9 \cdot 85$ & 7.57 & 16.66 & 13.95 & 0.99 & 0.70 \\
\hline Mean & 4.57 & 4.26 & $2 \cdot 34$ & $\mathrm{I} \cdot 85$ & $7 \cdot 50$ & 6.54 & $4 \cdot 52$ & 3.59 & $8 \cdot 67$ & $6 \cdot 56$ & $0.3 \mathrm{I}$ & 0.22 \\
\hline
\end{tabular}

observation agrees with the conclusions of Heitman \& Hughes (1949) and Mangold, Hazen \& Hays (1967).

The efficiency of food utilization was not affected by environmental temperature under the conditions of this experiment, except that there was a significantly better food utilization at $30^{\circ}$ in Expt $2(P<0.05)$.

TPP stimulation per cent. TPP stimulation per cent (calculated from hexose formation) increased with time, and this increase was proportional to the decrease in dietary 


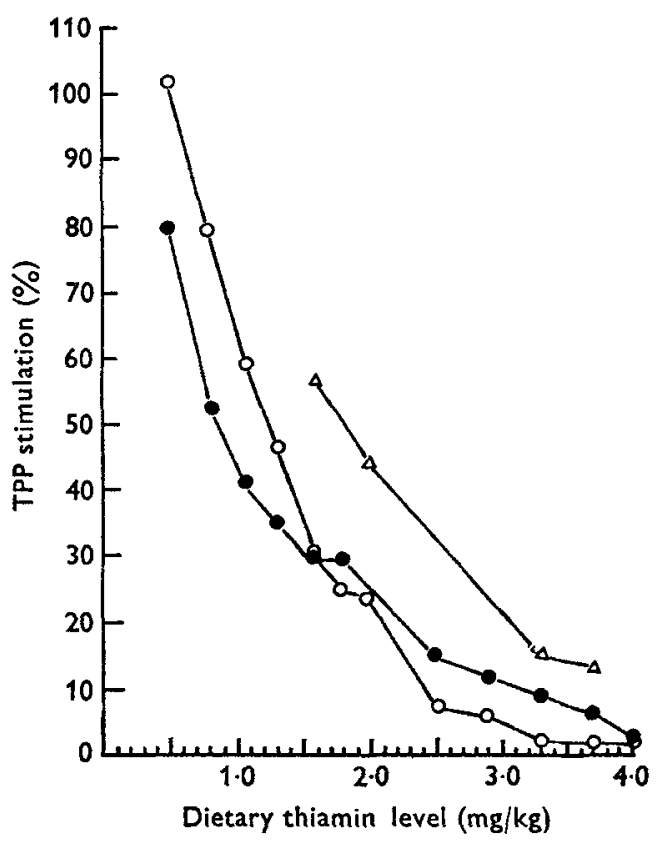

Fig. I. The relationship between dietary thiamin levels and the thiamin pyrophosphate (TPP) stimulation per cent (see p. I) in pigs at the end of the 8th week of experiments at different environmental temperatures. $\mathrm{O}-\mathrm{O}, 20^{\circ} ;-1,30^{\circ} ; \triangle-\triangle, 35^{\circ}$.

thiamin level as shown in Tables $3-5$. The differences in mean TPP stimulation per cent between dietary thiamin levels were significant $(P<0.01)$ in almost all instances. Temperature had a significant effect on TPP stimulation per cent. In Expt $\mathrm{x}$, the TPP stimulation per cent for pigs raised at low temperature $\left(20^{\circ}\right)$ was significantly higher $(P<0.01)$ than for those raised at the high temperature $\left(30^{\circ}\right)$ at the level of 0.60 and $0.85 \mathrm{mg}$ thiamin $/ \mathrm{kg}$ diet, but did not show a significant difference at the level of $\mathrm{r} \cdot \mathrm{ro}$ and $\mathrm{r} \cdot 35 \mathrm{mg}$ thiamin $/ \mathrm{kg}$ diet. In Expt 2, the TPP stimulation per cent for pigs raised at $35^{\circ}$ was significantly $(P<0.01)$ higher than for those raised at $20^{\circ}$ or $30^{\circ}$ with the same dietary thiamin level, but there was no significant difference between $20^{\circ}$ and $30^{\circ}$. In Expt 3, the TPP stimulation per cent was highly significantly $(P<0.00 \mathrm{I})$ greater at $35^{\circ}$ than at $20^{\circ}$ or $30^{\circ}$; and it was significantly higher $(P<0.01)$ at $30^{\circ}$ than at $20^{\circ}$. To summarize the results, Fig. $I$ was plotted to show the inverse relationship between TPP stimulation per cent and the dietary thiamin level at the end of the 8th week of the experiment. The TPP stimulation per cent was decreased with increasing dietary thiamin level from $0.60 \mathrm{mg}$ to $4.0 \mathrm{mg} / \mathrm{kg}$ diet. When dietary thiamin was increased to $3.3 \mathrm{mg} / \mathrm{kg}$ for pigs at $20^{\circ}$ and to $4.0 \mathrm{mg} / \mathrm{kg}$ for pigs at $30^{\circ}$, the TPP stimulation per cent did not increase substantially through the 8-week experimental period. With a further increase in air temperature up to $35^{\circ}$, the TPP stimulation per cent decreased with increasing thiamin level, but it did not reach the normal level value when dietary thiamin was as high as $3.7 \mathrm{mg} / \mathrm{kg}$ diet. When the dietary thiamin levels were plotted against the mean value for the TPP stimulation per cent for pigs for weekly values during the 8 -week periods, the trend was the same as in Fig. I. Under 
these experimental conditions, environmental temperature had an effect on the thiamin requirement of growing-finishing pigs; their thiamin requirement, expressed as $\mathrm{mg} / \mathrm{kg}$ diet, increased with increasing environmental temperature. The thiamin requirements were approximately $3.3 \mathrm{mg} / \mathrm{kg}$ and between 3.7 and $4.0 \mathrm{mg} / \mathrm{kg}$ for animals at $20^{\circ}$ and $30^{\circ}$, respectively. With an environmental temperature of $35^{\circ}$, the thiamin requirement, as estimated from the rate of change in TPP stimulation per cent, was greater than $4.0 \mathrm{mg} / \mathrm{kg}$. These results are in general agreement with the results of rat experiments reported by Mills (194I, I942-3), the results of chick experiments reported by Mills, Cottingham \& Taylor (1947), and the results with pigs reported by Mitchell (1964) that thiamin requirement per unit of diet is increased at high temperatures. The thiamin requirement of growing-finishing pigs obtained from these experiments using TPP stimulation per cent as a criterion is much higher than the requirement reported by earlier workers (Hughes, I940; Van Etten, Ellis \& Madsen, I940; Ellis \& Madsen, I944), Agricultural Research Council (1967) and (US) National Research Council (I968) apparently using growth rate as the primary criterion. This difference is due to the greater sensitivity of TPP stimulation per cent, which is a specific method for measuring marginal thiamin deficiency. Our results are lower than the requirement reported by Heinemann, Ensminger, Cunha \& McCulloch (1946). These workers estimated the thiamin requirement for maximum growth to be $4.5 \mathrm{mg} / \mathrm{kg}$ dietary dry matter.

The TPP stimulation per cent of pigs receiving $0.6-\mathrm{I} \cdot \mathrm{I} \mathrm{mg}$ thiamin $/ \mathrm{kg}$ diet was significantly higher at the lower $\left(20^{\circ}\right)$ than the higher temperature $\left(30^{\circ}\right)$ (Fig. I). The magnitude of this difference between the two temperatures with the same dietary treatment was decreased with increasing dietary thiamin level. This might indicate that the absolute amount of thiamin intake, even though accompanied by an increased food intake, could not meet to the same degree the requirement per unit of metabolic body-weight at the low temperature as at the higher one. It is suggested that the thiamin requirement per unit of metabolic body-weight might be higher at the lower temperature $\left(20^{\circ}\right)$ than that at $30^{\circ}$. (The requirement was calculated from the results mentioned above for pigs raised at $20^{\circ}$ as $0.396-0.437 \mathrm{mg} / \mathrm{kg}^{0.75}$ and those raised at $30^{\circ}$ require $0.366-0.384 \mathrm{mg} / \mathrm{kg}^{0.75}$.) With increasing dietary thiamin up to $\mathrm{I} \cdot 35$ and $\mathrm{I} .60 \mathrm{mg} / \mathrm{kg}$ diet, the TPP stimulation per cent was about the same at both temperatures. This indicates that the absolute amount of thiamin intake at these thiamin levels and in this temperature range is able to maintain the same TPP stimulation per cent at both temperatures. When the thiamin level rises beyond $1.8 \mathrm{mg} / \mathrm{kg}$ diet, the increased food intake in the cold (and therefore increased total thiamin consumption) could compensate for the increased thiamin requirement per unit metabolic bodyweight due to cold exposure. Thus, the TPP stimulation per cent was lower at the lower temperature $\left(20^{\circ}\right)$.

Blood transketolase activity. Blood transketolase activity at the end of the 7 th week of the experiment varied with the dietary content of thiamin, as shown in Tables I and 2. Thiamin level significantly influenced the enzyme activity. Pigs receiving higher thiamin levels had significantly higher $(P<0.05)$ mean enzyme activities than those receiving lower thiamin levels, except at $20^{\circ}$ and $30^{\circ}$ in $\operatorname{Expt} 3$, where there was 
no significant difference between thiamin levels. These results showing that enzyme activity increased with increasing dietary thiamin are in general agreement with Brin's (1962) report on erythrocyte transketolase and the report of Cheng, Koch \& Shank (1969) on liver transketolase in rats. An increase of thiamin from 3.3 to $3.7 \mathrm{mg} / \mathrm{kg}$ diet did not significantly increase the enzyme activity at $20^{\circ}$ or $30^{\circ}$, but it did so at $35^{\circ}$ (Table 1 ). The highest level recorded in any experiment was at a thiamin level of $4^{\circ} \circ \mathrm{mg} / \mathrm{kg}$ at $30^{\circ}$. As judged by erythrocyte transketolase activity, the thiamin requirement of growing-finishing pigs at different temperatures was similar to estimates obtained by using TPP stimulation per cent as the criterion. The enzyme activity when pre-incubated with TPP was significantly higher $(P<0.05)$ than enzyme activity without TPP. This observation indicated that there was a shortage of coenzyme in the deficient condition. Enzyme activity tended to be lower with increasing environmental temperature with the same dietary treatment, and the difference was statistically significant $(P<0.05)$ in Expt 3 when the activity was measured without TPP.

Temperature and thiamin requirement. The lower thiamin requirement of approximately $3.3 \mathrm{mg} / \mathrm{kg}$ diet at $20^{\circ}$ than at $30^{\circ}$ or $35^{\circ}$ is of interest. A possible explanation may be the increase in food consumption observed at the lower temperature and therefore an increased absolute amount of thiamin intake. This suggests that the concentration of thiamin in the diet needed to meet the requirements of the pigs must be increased at higher temperatures.

This study is one of a series from a co-operative project between the US Department of Agriculture and the Departments of Agricultural Engineering and Animal Science of the University of California. The authors express their appreciation to T. E. Bond and R. L. Givens of the U.S.D.A. and S. R. Morrison, Department of Agricultural Engineering, University of California, for their assistance and advice during the course of the various experiments.

\section{REFERENCES}

Agricultural Research Council (1967). The Nutrient Requirements of Farm Livestock No. 3, Pigs p. 263. London: Agricultural Research Council.

Brin, M. (1962). Ann. N.Y. Acad. Sci. 98, 528.

Cheng, C. H., Koch, M. \& Shank, R. E. (1969). F. Nutr. 98, 64.

Duncan, D. B. (r955). Biometrics 2, I.

Ellis, N. R. \& Madsen, L. L. (1944). Y. Nutr, 27, 253.

Ershoff, B. H. (1950). Archs Biochem. 28, 299.

Givens, R. L., Morrison, S. R., Bond, T. E. \& Miller, C. R. (1971). Rep. agric. Res. Serv. U.S. $42-191$.

Grab, W. \& Lancy, K. (1944).Klin. Wschr. 21/26, 230. Quoted by D. A. Vaughan \& L. N. Vaughan (1957).

Hart, J. S. (1958). Fedn Proc. Fedn Am. Socs exp. Biol. 17, 1045.

Hegsted, D. M. \& McPhee, G. S. (1950). Y. Nutr. 41, 127.

Heinemann, W. W., Ensminger, M. E., Cunha, T. J. \& McCulloch, E. C. (1946). J. Nutr. 3I, 107.

Heitman, H. Jr \& Hughes, E. H. (1949). F. Anim. Sci. 8, 17 r.

Heitman, H. Jr, Kelly, C. F. \& Hughes, E. H. (1949). F. Anim. Sci. 8, 459.

Hughes, E. H. (1940). J. Nutr. 20, 239.

Mangold, D. W., Hazen, T. E. \& Hays, V. W. (1967). Trans. ASAE ro, 370.

Mills, C. A. (1941). Am. F. Physiol. 133, 525.

Mills, C. A. (1942-3). Archs Biochem. 1, 73 . 
Mills, C. A., Cottingham, E. \& Taylor, E. (1947). Am. F. Physiol. r49, 376.

Mitchell, H. H. (1 964). Comparative Nutrition of Man and Domestic Animals.Vol. 2, p. 21 2. New York: Academic Press.

National Research Council (1968). Nutrient Requirements of Domestic Animals No. 2, Nutrient Requirements of Swine. Washington, DC: National Research Council.

Peng, C.-L. \& Heitman, H. Jr (1973). Br. F. Nutr. 30, 39 I.

Van Etten, C., Ellis, N. R. \& Madsen, L. L. (1940). F. Nutr. 20, 607.

Vaughan, D. A. \& Vaughan, L. N. (I957). F. Nutr. 63, 417. 